\title{
Design on soil-nailing wall Supporting of Foundation Pit in Bao Tou
}

\author{
Yingzi Yin ${ }^{1, a}$, Ya-li Xu ${ }^{1, b}$ \\ ${ }^{1}$ The school of architecture and civil engineering, Inner Mongolia University Of Science \& \\ Technology, Baotou 014010, China \\ a811489571@qq.com \\ b1050277615@qq.com
}

Keywords:deep foundation pit; soil-nailing wall; design; check

Abstract:According to the surrounding environment condition, the rock engineering site condition and the excavation depth, soil-nailing wall as its main form combining with the practical engineering case.the paper introduces the characteristics of the engineering and design soil-nailing wall excavation and check anti-bump and anti-overturning.to meets project requirements.

Soil nailing wall retaining structure are widely used in soil nailing construction because of simple construction, high construction efficiency, flexible, light structure, low engineering cost. For the calculation of soil nail, the typical specification method is the construction of foundation pit supporting technology regulation method ${ }^{[1]}$ and the regulations of technology of soil nailing supporting of foundation pit $^{[2]}$, but the calculation method is not the same . There are some research methods calculate soil nail force and displacement ${ }^{[3-4]}$. Finite element numerical analysis is also useful, but it is more complex and inconvenience promotion in terms of engineering practicability. This paper uses the construction of foundation pit supporting technology ${ }^{[1]}$ to meet the engineering requirements. It provide a reference for similar project.

\section{Project Summary}

Proposed site is located in the north of the west of the east river road at bao tou. The side of the building has leisure square and commercial shop and underground garage on the north and south of village .The excavation depth is 11 meters .

\section{Engineering geology}

According to the geological survey report, the soil is divided into miscellaneous fill,collapsible loess, silt, coarse sand. The physical and mechanical indexes of soil are shown in table 1.

Table 1 Physical and mechanical properties of soils

\begin{tabular}{rlcccc}
\hline Layer & soil type name & $\begin{array}{l}\text { Layer } \\
\text { thickness }(\mathrm{m})\end{array}$ & Severe $\left(\mathrm{kN} / \mathrm{m}^{3}\right)$ & $\begin{array}{l}\text { cohesive } \\
\text { force }(\mathrm{kPa})\end{array}$ & Angle of internal friction $\left(^{\circ}\right)$ \\
\hline 1 & miscellaneous fill & 2.60 & 16.0 & 5.0 & 15.0 \\
2 & collapsible loess & 3.40 & 16.1 & 13.1 & 22.0 \\
3 & scoarse sand & 1.40 & 19.0 & 0.0 & 40.0 \\
4 & silt & 9.10 & 18.9 & 13.9 & 22.0 \\
\hline
\end{tabular}

\section{edetermination of supporting schemes}

According to the construction of foundation pit supporting technology regulations (JGJ120-2012)[1],the engineering safety set the secondary level.Considering the surrounding area is smooth and the soil quality is good, no buildings around,soil nailing can meet the requirements, but we will strictly control the deformation of foundation pit. 


\section{the calculation of soil nailing}

\section{Calculate of soil nailing}

According to the engineering geology and the surrounding environment, the foundation pit engineering arrange7 soil nail.Index of soil nailing are shown in table 2 .

\section{calculation of earth pressure}

The earth pressure calculation method is the Rankine's earth pressure theory of foundation pit supporting technology regulation. The lateral earth pressure of graphics is the triangular distribution, the soil pressure distribution pattern of soil nail length increases with the increase of the depth of foundation pit.

Coefficient of earth pressure: $\mathrm{Ka}=\tan 2\left(45^{\circ}-\varphi / 2\right)$

Intensity of soil nail force: $E=\left(q+\gamma h_{1}\right)-2 c \sqrt{K a}$

In the formula:q-ground overload $r_{i}-i$ row of soil nailing in severe soil layer soil

$\mathrm{h}_{\mathrm{i}} \mathrm{i}$ row of soil nail distance on the surface of the side slope distance

Kai-i row of soil nailing in the active earth pressure coefficient of soil layer soil

Table2 Design parameters of soil-nail

\begin{tabular}{|c|c|c|c|c|c|}
\hline $\begin{array}{l}\text { number of soil } \\
\text { nail }\end{array}$ & $\begin{array}{l}\text { Vertical distance } \\
\text { (m) }\end{array}$ & $\begin{array}{l}\text { horizontal } \\
\text { distance(m) }\end{array}$ & spacing & $\begin{array}{l}\text { horizontal } \\
\text { angle }\left(^{\circ}\right)\end{array}$ & $\begin{array}{l}\text { Soil nail } \\
\text { aperture }(\mathrm{mm})\end{array}$ \\
\hline 1 & 1.5 & 1.5 & & 10 & 110 \\
\hline 2 & 1.5 & 1.5 & & 10 & 110 \\
\hline 3 & 1.5 & 1.5 & & 10 & 110 \\
\hline 4 & 1.5 & 1.5 & & 10 & 110 \\
\hline 5 & 1.5 & 1.5 & & 10 & 110 \\
\hline 6 & 1.5 & 1.5 & & 10 & 110 \\
\hline 7 & 1.5 & 1.5 & & 10 & 110 \\
\hline
\end{tabular}

\section{calculate of tensile load standard value}

In accordance with the provisions of slope of soil nail wall, so it need put on slope soil pressure reduction. This project adopts the single-stage slope soil nail wall. In accordance with the relevant provisions, single soil nail tensile load standard values can be pressed. $T_{j k}=\frac{\xi_{e_{a j k}} \mathrm{~s}_{\mathrm{xj}} \mathrm{s}_{\mathrm{yj}}}{\cos \alpha_{\mathrm{j}}}$

In the formula: $\mathrm{T}_{\mathrm{jk}}$ - tensile load standard values of the $\mathrm{j}$ root soil nail $\xi$ - load reduction factor

$\mathrm{E}_{\mathrm{ajk}}-\mathrm{j}$ root soil nail location of foundation pit horizontal load standard values

$\mathrm{S}_{\mathrm{xj}}, \mathrm{S}_{\mathrm{yj}}$-horizontal and vertical spacing of the $\mathrm{j}$ root soil nail and soil nailing adjacen

$\alpha_{j}$ - angle of the soil nailing with horizontal plane

$\beta$ - soil nail wall slope and the horizontal plane angle $-\varphi_{\mathrm{k}}$-angle of internal friction values

The first layer of soil:miscellaneous fill $(2.6 \mathrm{~m}), \beta=63.4^{\circ}, \varphi_{k}=15^{\circ}, \xi 1=0.554$

The second layer of soil:collapsible loess $(2.6 \mathrm{~m}-6.0 \mathrm{~m}), \beta=63.4^{\circ}, \varphi \mathrm{k}=22^{\circ}, \xi 2=0.485$

Similarly, $\xi 3=0.276, \xi 4=0.485$

Therefore, the above results are shown in table 3.

\section{length of soil nail design}

Length of soil nail design is directly related to the safety of the foundation pit slope stability, it is also the important factors that affect the project cost. Length of soil nail Divided into anchorage length and free length.

anchorage length:

$$
l_{b i}=T_{i} \gamma_{s} / \pi d_{i} \tau_{i}
$$

In the formula: $\mathrm{r}_{\mathrm{s}}$ - bearing capacity of soil nail tensile subentry coefficient, it takes 1.6 
$\mathrm{d}_{\mathrm{i}}$-solid diameter of root soil nailing anchor, it takes $110 \mathrm{~mm}$

free length:

$\mathrm{t}_{\mathrm{i}}$-soil nail through the layer of soil with anchor solid limit friction resistance standard

$$
l_{a i}=\frac{\left(h-h_{i}\right)\left[\tan \left(90^{\circ}-\frac{\beta+\phi_{k}}{2}\right)\right]}{\sin \left(180^{\circ}-\phi_{k}-\frac{\beta+\phi_{k}}{2}\right)} \sin \left(180^{\circ}-\frac{\beta+\phi_{k}}{2}\right)
$$

In the formula: $\beta$-soil nail wall slope and the horizontal plane angle

$\varphi_{\mathrm{k}}$-angle of internal friction values $\mathrm{h}$-the depth of foundation pit excavation

$\mathrm{h}_{\mathrm{i}}$ - the height of the top layer of soil nail

Length of soil nail: $l_{b i}=T i \gamma_{s} / \pi d_{i} \tau_{i}$

\section{Table3The calculation results of soil parameters}

\begin{tabular}{c|c|c|c|c}
\hline $\begin{array}{c}\text { The } \\
\text { number of } \\
\text { soil nail }\end{array}$ & $\begin{array}{c}\text { Earth } \\
\text { pressure } \\
(\mathrm{KN})\end{array}$ & $\begin{array}{c}\text { Reduction } \\
\text { factor }\end{array}$ & $\begin{array}{c}\text { Tensile load } \\
\text { standard values } \\
(\mathrm{KPa})\end{array}$ & $\begin{array}{c}\text { Length of } \\
\text { soil nail } \\
(\mathrm{m})\end{array}$ \\
\hline 1 & 14.43 & 0.554 & 18.26 & 5.8 \\
2 & 9.45 & 0.485 & 10.47 & 5.4 \\
3 & 20.42 & 0.485 & 22.62 & 5.7 \\
4 & 31.38 & 0.485 & 35.28 & 4.6 \\
5 & 33.61 & 0.276 & 21.19 & 6.6 \\
6 & 64.08 & 0.485 & 70.99 & 8.8 \\
7 & 76.95 & 0.485 & 85.30 & 6.4 \\
\hline
\end{tabular}

Figure 2 Observation point of foundation

\section{Stability checking}

\section{The anti slip}

According to the Specification for supporting technology building foundation pit[1],the anti sliding stability safety factor of soil nailing wall should satisfy this condition:Ks $>1.3$. The anti slip stability of foundation pit slope checking should be pressed type: $K_{k}=F_{t} / E_{a}$

In the formula: $\mathrm{K}_{\mathrm{k}}$-The safety factor of anti sliding $\mathrm{F}_{\mathrm{t}}$-Anti sliding force on the wall bottom section Ea -Wall active soil pressure

The anti sliding force on the wall bottom section is: $F_{t}=\left(B \cdot S_{h} \cdot H \cdot \gamma+B \cdot S_{h} \cdot q\right) \tan \varphi+c B S_{h}$

The wall active soil pressure of unit width is: $E_{a}=q H K_{a}+1 / 2 \gamma H^{2} K_{a}-2 c \sqrt{K_{a}}+2 c^{2} / \gamma$

In the formula:B - Wall width, $\mathrm{B}=11 / 12 \mathrm{LCOS} \alpha \quad \mathrm{c}$-Each layer cohesion weighted average

$$
\begin{aligned}
& \mathrm{S}_{\mathrm{h}} \text { - Average space of soil nail } \mathrm{H} \text {-Vertical height of foundation pit } \\
& \gamma \text { - } \mathrm{q} \text { - } \text {-Toil severe overload value of foundation pit } \\
& \varphi \text { - Weighted average value of friction angle in each layer } \\
& \mathrm{K}_{\mathrm{a}} \text { - Coefficient of active earth pressure }
\end{aligned}
$$

So: $\mathrm{Ft}=942.305, \mathrm{Ea}=384.39, \mathrm{~K}_{\mathrm{k}}=\mathrm{F}_{\mathrm{t}} / \mathrm{Ea}=2.45 \geq 1.3$, Meet anti sliding checking. 


\section{The Anti overturning}

According to the Specification for supporting technology building foundation pit[1],the anti sliding stability safety factor of soil nailing wall should satisfy this condition:Ks $>1.3$. The anti overturning of foundation pit slope checking should be pressed type: $\quad K_{q}=\frac{M_{w}}{M_{0}} \geq 1.5$

In the formula:, $M_{w}=1 / 2 B\left(B \cdot S_{h} \cdot H \cdot \gamma+B \cdot S_{h} \cdot q\right) \quad M_{o}=\frac{1}{2} H \cdot E_{a}$

$\mathrm{M}_{\mathrm{w}}=5306.05, \mathrm{M}_{\mathrm{o}}=2114.16, \mathrm{~K}_{\mathrm{q}}=\mathrm{M}_{\mathrm{w}} / \mathrm{M}_{\mathrm{o}}=2.51 \geq 1.5$, Meet anti overturning checking.

Through calculation and analysis,the soil nailing wall internaland external stability could meet the design requirements.

\section{Foundation pit monitoring}

According to the relevant regulations and requirements of design[5],Combined with the specific circumstances of the project, the monitoring scheme is as follows: in the surface layer of the top surface (pit apron) buried observation point, distance of about 20 meters.In the foundation pit top embedment length is about $150 \mathrm{~mm}$ with a steel tape, steel tape fixed by cement mortar, as shown in Figure 2.

In the reference point on both sides of angle displacement observation of foundation pit, to ensure the two basis point visibility line through all of the observation point. The foundation pit monitoring content of this project is mainly on the top layer displacement monitoring, monitoring results show: The maximum horizontal displacement of foundation pit side slope is $11.4 \mathrm{~mm}$, far less than $0.3 \% \mathrm{H}(\mathrm{H}$ is the excavation depth and the maximum displacement monitoring value).

\section{Conclusion}

(1)Through the design and calculation of soil nailing support scheme, checking the anti sliding coefficient, anti overturning are respectively $2.45,2.51$, both to meet the safety requirements, meet the needs of engineering.

(2)The monitoring results show that the maximum horizontal displacement of foundation pit slope, the slope of $11.4 \mathrm{~mm}$ specification, no obvious cracks, shows that the soil nailing system.

(3)The construction of foundation pit with soil nailing,effectively control the deformation of foundation pit, and achieved good results.

\section{References:}

[1]The national standard of the people's Republic of China.JGJ120-2012 Specification for supporting technology building foundation pit[S].China Building Industry Press,2012.In Chinese.

[2]The national standard of the people's Republic of China.JGJ120-2012 Technical specification for retaining and protection of foundation pit soil nail[S].China Building Industry Press,2012.In Chinese.

[3]Hongxian Guo,Erxiang Song,Zhaoyuan Chen.Analysis of the axial forces of soil nails during construction[J].Journal of Civil Engineering,2007,20(11).In Chinese.

[4]Zhikun Guo,Jingdong Yang,Shuguang Ma.Incremental calculation method of soil nails internal force[J].Journal of PLA University of Science and Technology (NATURAL SCIENCE EDITION),2005,6(4).In Chinese.

[5]Junyan Guo.GB50497- 2009Manual implementation of technical code for monitoring of building foundation pit engineering[S].Building Industry Press,2010.In Chinese. 